\title{
THE NATURE OF DUCTILE DEFORMATION IN THE PHYLLITE-QUARTZITE UNIT (EXTERNAL HELLENIDES)
}

\author{
Xypolias P. and Chatzaras V. \\ Department of Geology, University of Patras, 26500 Patras - Greece; p.xypolias@upatras.gr
}

\begin{abstract}
This work describes the nature of ductile deformation in the Phyllite-Quartzite $(P Q)$ unit in terms of structural evolution and spatial variation of finite strain and vorticity of flow. The $P Q$ unit is affected by at least three ductile deformation $\left(D_{1,2}, 3\right)$ phases. However, the $D_{2}$ is the dominant phase resulting in the formation of a penetrative foliation $\left(S_{2}\right)$ which is by far the most common structural feature in all scales of observation. A stretching lineation $\left(L_{2}\right)$, which trends perpendicular to the structural grain of the belt, is well-developed within the $S_{2}$ plane. Numerous kinematic criteria clearly indicate west (or south)-directed transport of the $P Q$ unit during $D_{2}$. This phase is also characterized by a systematic non-linear increase of strain ratio (Rxz) with proximity to the Basal thrust. Spatial variation of kinematic vorticity number reveals an increase of pure shear component of $D_{2}$ deformation towards the middle structural levels of the unit. These results are used to discuss the validity of various geodynamic models related to the exhumation of the $P Q$ unit.
\end{abstract}

Key words: Progressive deformation; finite strain; vorticity; high-pressure rocks; Greece.

\section{Introduction}

The metamorphic rocks of the Phyllite-Quartzite (PQ) unit belong to the External Hellenides and constitute a Late Oligocene-Early Miocene high pressure-low temperature (HP-LT) belt, which extends over a distance of $600 \mathrm{~km}$. Over the last two decades, several tectonic models for the exhumation of the PQ unit have been proposed, including underplating with symmetric syn-orogenic (Fassoulas et al. 1994) or asymmetric syn-(or post-) orogenic extension (Jolivet et al., 1996), delamination of the subducting crust followed by buoyancy-driven exhumation (Thomson et al., 1999), solid-state ductile extrusion contemporaneous with continent-continent collision (Xypolias and Doutsos, 2000; Doutsos et al., 2000) as well as gravitational collapse and erosion of a thickened crustal wedge (Zulauf et al., 2008). Each of these models predicts different structural settings and requires different deformation paths for the PQ unit rocks. For example, models of syn-orogenic extension require the creation of large extensional detachments and the formation of extensional sedimentary basins in the upper plate, the model of buoyancy-driven exhumation suggests that the bulk of the PQ unit was escaped upward as a coherent block, unaffected by any pervasive deformation. The ductile extrusion model, in turn, suggests that the exhumation was achieved by upward transport-parallel elongation of the PQ unit rocks and requires penetrative ductile deformation. Therefore, it is clear that despite numerous studies in the area, the mechanism related to the exhumation of the PQ unit is still a matter of debate. Much of the debate stems from the fact that there is also no consensus for the internal structure and tectonic evolution of the PQ unit. This work summarises the results of qualitative and quantitative structural analyses performed in the unit mainly over the last decade and uses these to discuss the applicability of various geodynamic models. 


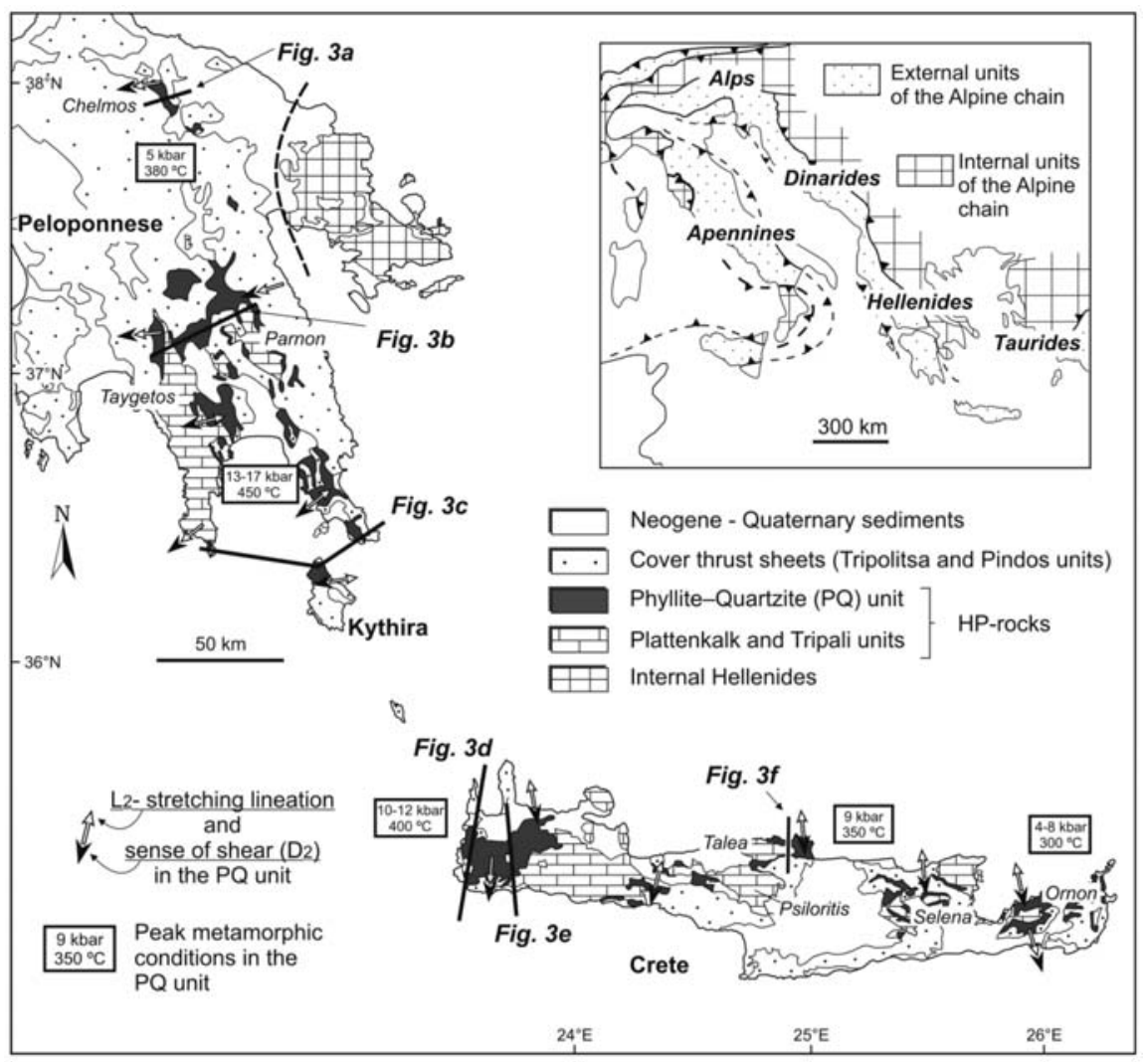

Fig. 1: Simplified geological map of the southwest External Hellenides. $L_{2}$ stretching lineation, sense of shear $\left(\mathrm{D}_{2}\right)$ and peak metamorphic conditions in the PQ unit are also shown. Metamorphic data after Katagas et al. (1991), Theye et al. (1992), Blumör (1998). Inset: generalized map of the Alpine chain in southeastern Europe (modified after Xypolias et al. 2007).

\section{Geological setting}

The External Hellenides are part of the Alpine Orogenic belt (Fig. 1a, inset) and form an orocline connecting the Dinarides to the NW with the Taurides to the SE. They mainly consist of Mesozoic and Cenozoic sedimentary rocks that were deposited on the rifted northern margin of the Apulia microcontinent. The present disposition of the External Hellenides is largely the result of progressive southward (in palaeo-coordinates) stacking of nappes/units (Fig. 1). Nappe stacking took place from Eocene to Early Miocene times, following the closure of the Pindos Ocean and the subsequent northward subduction and collision of the Apulia beneath the Pelagonian microcontinent (e.g. Doutsos et al., 1993, Xypolias and Doutsos, 2000).

The PQ unit is considered to be a metamorphosed Late Carboniferouse-Upper Triassic rift sequence consisting of phyllites, quartzites, metaconglomerates and marble intercalations (Robertson, 2006 and references therein). The thickness of the PQ unit is ca. $2 \mathrm{~km}$ in the central parts of the HP-belt (Kythira, westernmost Crete; Fig. 1) and decreases systematically towards its lateral tips (north Peloponnese, east Crete; Fig. 1) where it approaches ca. 1 km (Xypolias et al., 2007). Metamorphic conditions in the PQ unit (Fig. 1) decrease systematically in map-view from the central parts to the lateral 
tips of the belt (e.g. Theye et al., 1992). Peak P-T conditions have been constrained at $450 \pm 30{ }^{\circ} \mathrm{C}$ and 13-17 kbar (Theye et al. 1992, Blumör 1998) while the age of the metamorphic peak is constrained at 19-24 Ma (K-Ar and ${ }^{39} \mathrm{Ar}-{ }^{40} \mathrm{Ar}$ on white mica; e.g. Panagos et al., 1979, Seidel et al. ,1982). The PQ unit is tectonically emplaced on the Plattenkalk unit by a major ductile thrust (Greiling, 1982; Doutsos et al., 2000; Zulauf et al., 2002; Xypolias and Kokkalas, 2006), the "Basal thrust".

The structurally lower Plattenkalk unit is composed of Carboniferous-Eocene carbonate rocks overlain by an Oligocene limy metaflysch with metaconglomerate horizons (e.g. Kowalczyk et al., 1977). Metamorphic index minerals in the Plattenkalk unit have only been found in central Crete at the Talea Window and indicate P-T conditions of 7-10 kbar and ca. $350{ }^{\circ} \mathrm{C}$ (Theye et al., 1992). Exceptionally in west Crete, an Upper Triassic-Lower Jurassic carbonate sequence, the Tripali unit, lies tectonically between the Plattenkalk and the PQ units.

The PQ unit is, in turn, overlain by the Tripolitsa and Pindos units representing the cover thrust sheets (Fig. 1). The Pindos and Tripolitsa units are mainly composed of Triassic to Eocene carbonate rocks and an upper Eocene flysch. The Pindos unit tectonically rests on the Tripolitsa unit and both units have a combined structural thickness no greater than $6 \mathrm{~km}$. At the base of Tripolitsa carbonate rocks, a thin Permo-Triassic sequence, referred to as the Tyros Beds, which is in tectonic contact with the underlying PQ unit, has suffered very low-grade metamorphism $\left(200-350{ }^{\circ} \mathrm{C}, 3-6\right.$ kbar; e.g. Thieboult and Triboulet, 1984).

Unconformably above the Cretan nappe pile lies a Neogene sedimentary succession. Data from Crete indicate that sedimentation started with terrigenous deposits of Middle Miocene age, followed by Upper Miocene-Pleistocene fluviolacustrine and open-marine sediments (e.g. Kokkalas et al., 2006).

\section{Phases of ductile deformation}

Based primarily on overprinting criteria observed in map to outcrop scales as well as on microstructural data, three principal ductile deformation phases $\left(D_{1}-D_{3}\right)$ have been distinguished to constrain the structural evolution of the PQ unit (Greiling, 1982; Doutsos et al., 2000; Fassoulas et al., 1994; Zulauf et al., 2002; Kokkalas and Doutsos, 2004; Chatzaras et al., 2006; Xypolias et al., 2008). Deformation/metamorphism relationships described below in combination with the proposed P-T-t paths (Fig. 2) imply that these successive phases were coeval with progressive burial and exhumation of the PQ unit rocks.

\section{1 $D_{1}$ deformation}

The older recognized structures $\left(D_{1}\right)$ in the PQ Unit are tight to isoclinal folds with wavelengths ranging from a few $\mathrm{mm}$ to about $10 \mathrm{~cm}$. These structures are poorly preserved throughout the area due to intense $D_{2}$ ductile deformation and recrystallization. On outcrop scale, the $S_{1}$ fabric can be locally recognized mainly within thin competent quartzite layers (Fig. 2a), where it wraps around $\mathrm{F}_{2}$ fold closures while folded $\mathrm{S}_{1}$ within the phyllites is mainly visible on the microscale.

\section{2 $\mathrm{D}_{2}$ deformation}

Structures and fabrics generated during $\mathrm{D}_{2}$ deformation are pervasively developed throughout the PQ unit, and are by far the most common structural features observed in the field. This deformation phase is accompanied by a penetrative foliation $\left(\mathrm{S}_{2}\right)$ defined by the shape-preferred orientation of glaucophane and chloritoid needles as well as the alignment of micaceous films and elongated quartz aggregates (Fig. 2a). A mineral stretching and clast-elongation lineation $\left(\mathrm{L}_{2}\right)$ is well-developed within 


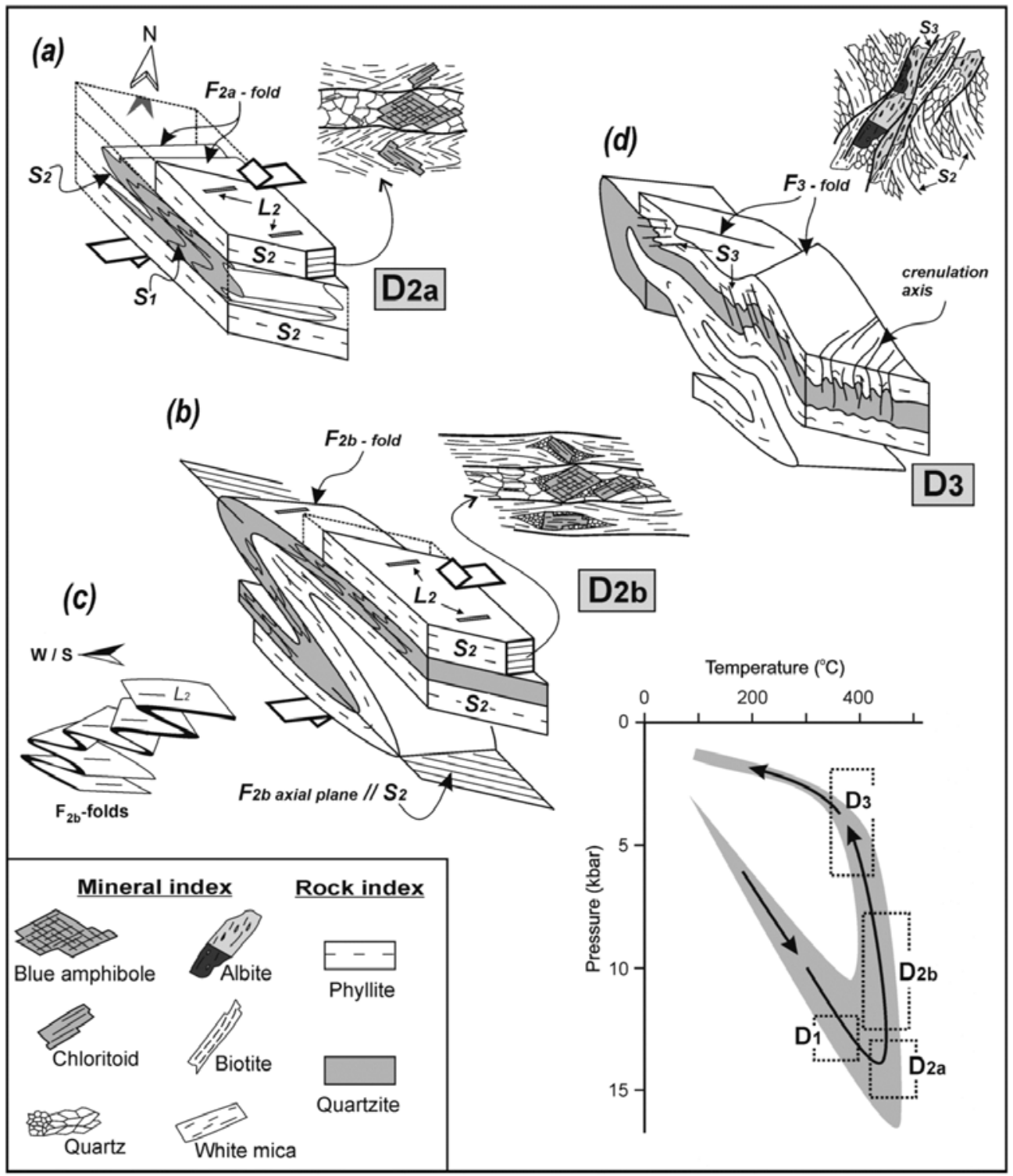

Fig. 2: Deformation/metamorphism relationships and progressive deformation of the PQ unit rocks. Block diagrams showing progressive deformation and associated structures during $\mathrm{D}_{2 \mathrm{a}}(\mathrm{a}), \mathrm{D}_{2 \mathrm{~b}}(\mathrm{~b})$ and $\mathrm{D}_{3}(\mathrm{~d})$ deformation subphases/phases, respectively. Line drawings summarize crystallization-deformation relationships. (c) Block sketch showing the rotation and tightening of F2b folds towards the lower structural levels of the PQ unit. The pressure-temperature path was constructed combining paths proposed by Blumör (1998) and Thomson et al. (1998) for the southern Peloponnese and western Crete, respectively. (Modified after Xypolias et al. 2008). 
the plane of $S_{2}$ (Fig. 2a). Throughout southwest Hellenides, $L_{2}$ systematically trends perpendicular to the structural grain of the belt (Fig. 1).

The $\mathrm{D}_{2}$ deformation can be subdivided in two successive increments $\left(\mathrm{D}_{2 \mathrm{a}}, \mathrm{D}_{2 \mathrm{~b}}\right)$ of ductile deformation. The earlier $\mathrm{D}_{2 \mathrm{a}}$ structures appear to be coeval with the main growth of HP-minerals (Fig. 2a) and can be locally recognized in the form of minor isoclinal folds $\left(\mathrm{F}_{2 \mathrm{a}}\right)$, which typically trend parallel to the regional $\mathrm{L}_{2}$ orientation. The second increment of $\mathrm{D}_{2}$ deformation is accompanied by outcrop-scale $\mathrm{F}_{2 \mathrm{~b}}$ folds. As $\mathrm{F}_{2 \mathrm{~b}}$ fold axes are sub-parallel or at a small angle to the $\mathrm{L}_{2}$ lineation and fold axial planes are parallel to the regional $S_{2}$ foliation (Fig. $2 b$ ), a genetic link between $S_{2} / L_{2}$ and fold development is suggested.

Throughout the PQ unit, it has been recorded a systematic relation between the orientation and style of folds with respect to the structural level in the unit. Specifically, at lower structural levels, the $F_{2 b}$ folds are isoclinal with their axes oblique to sub-parallel to the $\mathrm{L}_{2}$ while at progressively upper structural levels there is an increase in both the apical angle of the folds and the range of divergence between the fold axis and the $\mathrm{L}_{2}$ orientation (Fig. 2c; e.g. Xypolias and Doutsos, 2000; Chatzaras et al., 2006). This finding is indicative of a progressive rotation of fold axes into the $\mathrm{X}$-axis of finite strain (e.g. Alsop, 1992), resulting from an overall increase in strain magnitude as the contact between the PQ and the Plattenkalk units is approached.

Numerous kinematic indicators such as quartz c-axis fabrics, oblique grain shape fabrics, asymmetric boudins, sigma-shaped porphyroclasts, bookshelf tiling of HP-related minerals, S/C fabrics and single sets C'-type shear bands indicate a clear top-to-the-west (Peloponnese and Kythira) top-to-the-south (Crete) shear sense (Xypolias and Koukouvelas, 2001; Zulauf et al., 2002; Chatzaras et al., 2006). Evidence for top-to-the-east (or north) shearing (backward motion) has been mainly found at the upper structural levels of the PQ unit. Petrofabric data from central Peloponnese also reveals that west-directed ductile shearing in the PQ unit possibly occurred at deformation temperatures of $400-450{ }^{\circ} \mathrm{C}$, while the east-directed movements occurred at lower temperatures $\left(\mathrm{ca} .350{ }^{\circ} \mathrm{C}\right)$. These data imply that backward shearing occurred during the late stages of ductile deformation.

It is semantic to note that throughout the PQ unit quartzites show evidence of dynamic recrystallization accommodated by both subgrain rotation and low-temperature grain-boundary migration. This, in addition to the presence of strong quartz c-axes preferred orientation patterns recorded in Peloponnese and Kythira suggest that dislocation creep was the dominant deformation mechanism during $\mathrm{D}_{2}$ shearing (Xypolias and Kokkalas, 2006). Evidence for deformation by dissolution precipitation creep is mainly restricted to metasiltstones, where quartz clasts are embedded in a phyllosilicate-rich matrix and occasionally show pressure shadows on both sides of grains (Schwarz and Stockhert, 1996).

\section{3 $\mathrm{D}_{3}$ deformation}

The third deformation phase $\left(\mathrm{D}_{3}\right)$, is less widely developed than $\mathrm{D}_{2}$ and is mainly represented by centimetre- to metre scale folds $\left(\mathrm{F}_{3}\right)$ and crenulations deforming $\mathrm{S}_{2}$. The mesoscopic $\mathrm{F}_{3}$ folds are predominantly open with a gently inclined axial plane cleavage. Microstructural observations from Kythira have shown that discrete $\mathrm{S}_{3}$ cleavage domains serve as the site for growth of both biotite and albite. Corrosion of quartz and mica along this steeply dipping cleavage has also been recognized indicating that dissolution-mass transfer processes played an important role in their formation. Based on the above mentioned observations, it seems that $\mathrm{D}_{3}$ deformation commenced under ductile conditions and became progressively more brittle with time. 


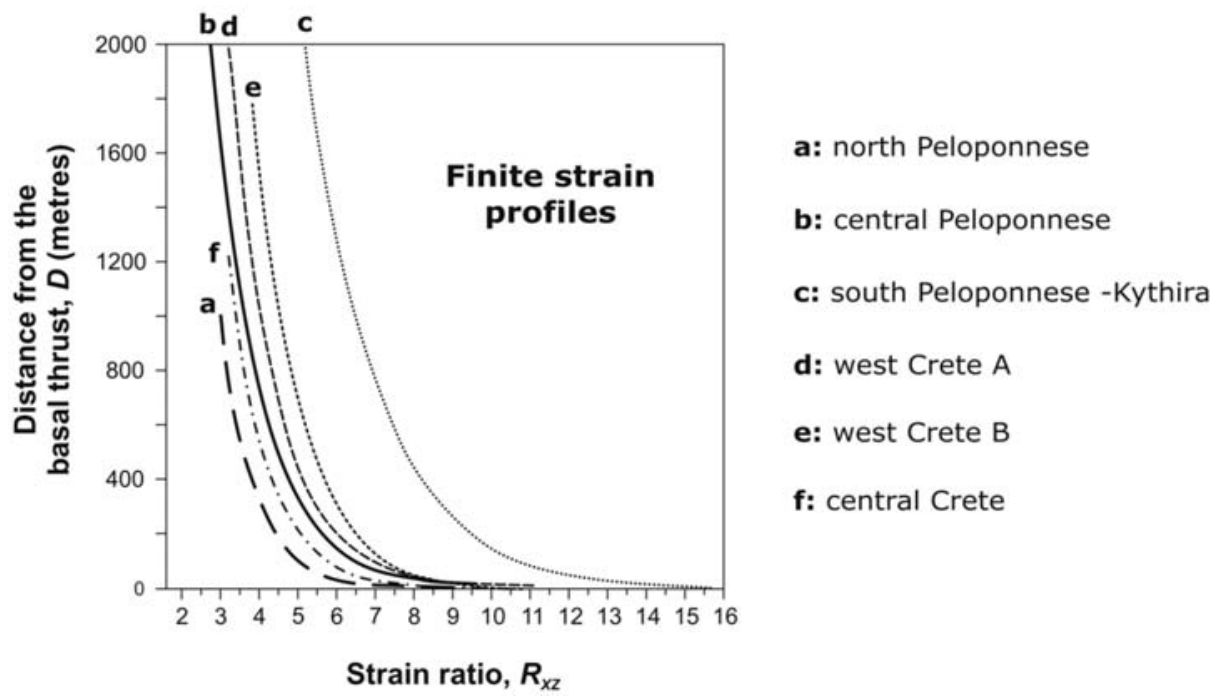

Fig. 3: The best fit curves describing the spatial variation of strain ratio along six traverses in the PQ unit. The location of these traverses is illustrated in Figure 1. (Modified after Xypolias et al. 2007)

\section{Finite strain}

Systematic analysis of the spatial variation of finite strain associated with $\mathrm{D}_{2}$ deformation in the PQ unit rocks has been carried out along six traverses (Xypolias et al., 2007 and references therein). The location of these traverses is illustrated in Figure 1. The analysis is based on a total of 200 oriented samples collected from different structural levels above the basal thrust. Finite-strain ratio $\mathrm{R}_{\mathrm{XZ}}$ was estimated using graphical and algebraic Rf/ $\phi$ methods (Lisle, 1994). Plastically deformed quartz grains and clasts in fine-grained metaconglomerates, metapsammites, metasiltstones and quartzites were used as strain markers. It is emphasized that strain analysis was not carried out in pure quartzites showing extensive dynamic recrystallization because the shape of the most deformed grains may have restored to more equant form. However, analysis was performed in a few quartzites that include slightly recrystallized quartz ribbons embedded in a fine grained matrix. The majority of analysed samples are characterized by the presence of mica aggregates that anastomose around plastically elongated quartz grains or clasts showing evidence of undulose extinction.

Data of the strain ratio (Rxz) were plotted against distance (D) from the basal thrust to examine the variation of $R_{X Z}$ values along the six traverses. The best fit curves describing the spatial variation of strain ratio in the PQ unit are illustrated in Figure 3. As a whole, the profiles show a systematic strain increase with proximity to the basal thrust. However, strain gradient is not constant from the top to the bottom of the shear zone. Specifically, the downward increase in strain ratio is slight at the upper and middle levels of the unit and becomes abrupt at a projected distance of $300 \mathrm{~m}$ above the basal thrust (Fig. 3). This progressive non-linear strain increase towards the basal thrust obeys a specific logarithmic function (see Xypolias et al., 2007 for details).

So far, less systematic analytical work about the shape of finite strain ellipsoid has been done. In Crete, the shape of strain ellipsoid varies from flattening via plane to prolate (Fassoulas et al., 1994; Zulauf et al., 2002). 3D strain data from north Peloponnese show slightly constrictional to plane strain conditions, with k being approximately 1.4 (Xypolias and Doutsos, 2000). 


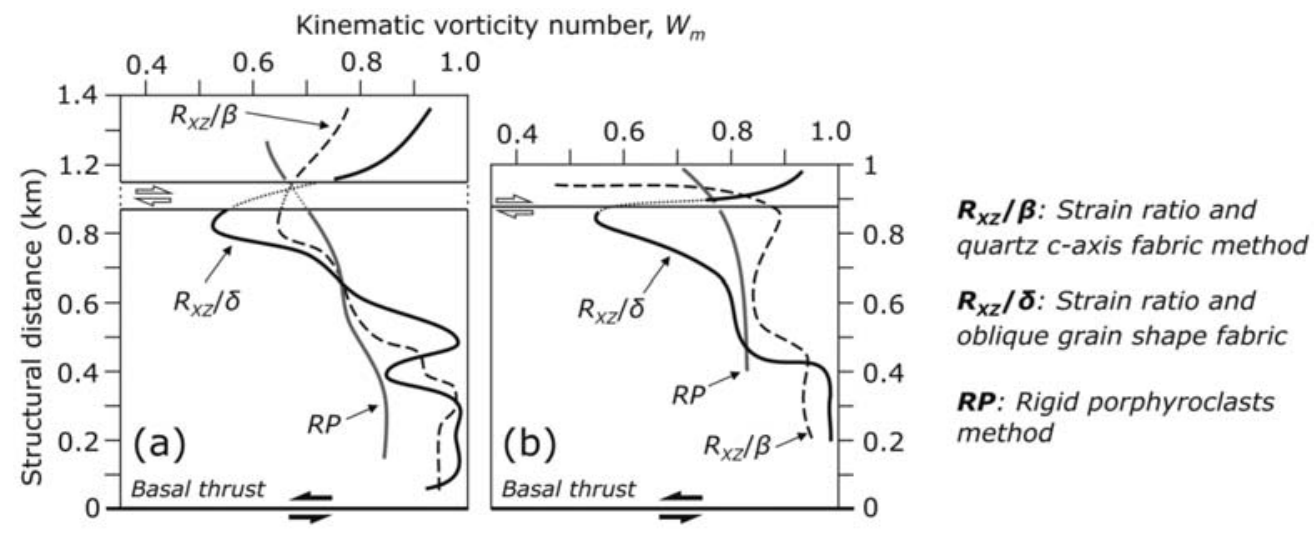

Fig. 4: Graphs (vorticity profiles) illustrating the vertical spatial variation in Wm values within the Phyllite-Quartzite unit in Taygetos (a) and Chelmos (a) areas. (Modified after Xypolias and Koukouvelas 2001; Xypolias 2009).

\section{Vorticity and ductile thinning}

Quantification of flow vorticity is also critically important for understanding the kinematics of rock flow in deformation zones. Mean kinematic vorticity number $(\mathrm{Wm})$ is the most commonly used numerical measure to specify the shear-induced vorticity caused by the non-coaxial component of deformation. Wm is considered as a non-linear relation between the pure shear and simple shear components of deformation, with $\mathrm{Wm}=1$ implying simple shear and $\mathrm{Wm}=0$ implying pure shear flow (Passchier, 1987). Vorticity analyses have been performed in the PQ unit rocks exposed in windows of Peloponnese (Chelmos, Taygetos, Parnon) using a variety of analytical methods such as (a) the rigid porphyroclast method (Passchier, 1987), (b) the finite strain / quartz c-axis fabric method (e.g. Wallis, 1995), (c) the quartz c-axis fabric / oblique grain shape fabric method (Wallis, 1995) and (d) the finite strain / oblique grain shape fabric method (Xypolias, 2009).

Figure 4 illustrates the spatial variation of Wm within the PQ unit in Taygetos and Chelmos areas (Xypolias and Koukouvelas, 2001; Xypolias, 2009). In both vorticity profiles, the general trend observed by 'averaging' the results of these methods is that the Wm value approaches 1 close to the basal thrust and decreases upwards reaching a value less than 0.71 (equal contribution of pure and simple shear) at the middle of the unit, below a zone of backward shearing. Above this zone, the Wm values generally increase.

Deviation from ideal simple shear deformation implies ductile thinning perpendicular to the boundaries of the PQ unit and resultant dip-parallel elongation. For isochoric plane strain deformation, the stretch magnitude both normal and parallel to the flow plane can be calculated, combining strain and vorticity data (e.g. Wallis, 1995). Such calculations in Taygetos area indicate that the average transport-parallel elongation appears to be higher in the middle structural levels of the PQ unit, ranging between 60 and $90 \%$, and lower in the deeper parts of the zone, ranging from $40 \%$ to $60 \%$. Less significant variation in ductile thinning normal to the zone has been recorded; it is on the order of 30-45\%.

\section{Discussion and conclusions}

It is clear, from both qualitative and quantitative analyses, that the PQ unit throughout the belt was af- 
fected by penetrative deformation during the ductile stage of exhumation. This finding is in constrast to models proposing exhumation of Cretan HP-rocks as a coherent block unaffected by any pervasive deformation (e.g. Thomson et al., 1999). They also propose that during buoyancy-driven exhumation, deformation was restricted to the vicinity of the upper bounding extensional detachment fault. Finite strain profiles, in turn, indicate a systematic non-linear increase of finite strain with proximity to the Basal thrust and do not support strain localization along the upper boundary of the unit. These findings also imply that accumulation of ductile strain was coeval with the emplacement of the PQ on the Plattenkalk units during west (or south)-directed thrusting.

Penetrative ductile deformation in the PQ unit was also associated with ductile thinning and transportparallel elongation of the material. However, the mechanism by which the ductile thinning and transport-parallel elongation contribute in exhumation of HP-nappes is not unique (e.g. Xypolias et al., 2010). Generally, two major alternative mechanisms have been proposed up to now. According to the first (e.g. Platt, 1993) a component of ductile extensional flow along a shallow dipping mid-crustal deformation zone requires the same component of deformation to be present in the surrounding rocks at the higher structural units. Under this mechanism the exhumation of HP-rocks is achieved by unroofing along the footwalls of low-angle normal faults (syn-orogenic extension). The most reliable indicators of this mechanism are the downward increase in the metamorphic pressure as well as the formation of extensional sedimentary basins in the upper plate (Platt, 1993). Alternatively, the transport-parallel elongation can contribute to the upward ductile extrusion of the HP-rocks (Escher and Beaumont, 1997; Xypolias and Koukouvelas, 2001; Law et al., 2004). In this case, the extruding/exhuming rock unit is modelled to represent a tectonic slice bounded by a basal subduction-related thrust fault and a roof stretching fault. The roof stretching fault may display normal or thrust sense, depending on the motion of the crust above the extruding material (e.g. Godin et al., 2006).

The mechanism of syn-orogenic (asymmetric or symmetric) extension has been adopted by many authors (e.g. Fassoulas et al., 1994; Jolivet et al., 1996) to explain the removal of overburden from above the PQ unit. However, the applicability of this mechanism remains highly questionable since either OligoceneEarly Miocene extensional related basins or normal-sense metamorphic breaks within the PQ unit have been not reported so far. Moreover, it is unclear if a thinning on the order of $30-45 \%$ in the upper plate is capable to denudate tectonically the PQ unit rocks. In contrast, several studies have shown that extension lagged behind a significant part of the exhumation process, and is superposed on an orogenic wedge that contains HP-rocks at relatively shallow crustal levels. According to these studies, middle Miocene-Pleistocene extension controlled both the exhumation of HP-rocks from $\sim 10 \mathrm{~km}$ to the surface and the initiation of basin formation (Papanikolaou and Vassilakis 2010 and references therein). However, these models seem to underestimate the importance of contraction-related structures deforming Middle Miocene-Early Pleistocene sediments of Crete (Kokkalas and Doutsos, 2001; Kokkalas et al., 2006; Chatzaras et al., 2006; Klein et al., 2008; Tortorici et al., 2010), suggesting that the role of extension is overestimated.

Consequently, solid-state ductile extrusion of PQ unit under continuous compression provides a reasonable explanation for the exhumation of these rocks. According to this mechanism, after peak metamorphism, the PQ unit was detached from its basement and extruded upward to the west (or south) between the basal thrust and the Tripolitsa basement at the top. The effect of this extrusion process was the emplacement of the PQ unit over the Plattenkalk unit bringing it into contact with the overlying cover thrust sheets along a roof stretching fault. The subduction-related basal thrust and roof stretching fault operated contemporaneously in a tectonic setting without any net extension of the overall system. However, as mentioned above the roof stretching fault may display normal (e.g. Crete) or thrust (e.g. Kythira) sense depending on the crust motion above this fault. 


\section{References}

Alsop, G.I., 1992. Progressive deformation and the rotation of contemporary fold axes in the Ballybofey Nappe, north-west Ireland. Geological Journal 27, 271-183.

Blumör, T., 1998. Die Phyllit-Qyarzit-Serie SE-Lakoniens (Peloponnes, Griechenland): Hochdruckmetamorphite in einem orogenen Keil. Frankfurter geowiss. Arb. A17.1-190.

Chatzaras, V., Xypolias, P., Doutsos, T., 2006. Exhumation of high-pressure rocks under continuous compression: a working hypothesis for southern Hellenides (central Crete, Greece). Geological Magazine $143,859-876$.

Doutsos, T., Koukouvelas, I., Poulimenos, G., Kokkalas, S., Xypolias, P., Skourlis, K., 2000. An exhumation model of the south Peloponnesus, Greece. International Journal of Earth Science 89, 350-365.

Doutsos, T., Piper, G., Boronkay, K., Koukouvelas, I., 1993. Kinematics of the Central Hellenides.- Tectonics 12, 936-953.

Escher, A., Beaumont, C., 1997. Formation, burial and exhumation of basement nappes at crustal scale: a geometric model based on the Western Swiss-Italian Alps. Journal of Structural Geology 19, 955-974.

Fassoulas, C., Kilias, A., Mountrakis, D., 1994. Post nappe stacking extension and exhumation of highpressure/low-temperature rocks in the island of Crete, Greece. Tectonics 13, 127-238.

Godin, L., Grujic, D., Law, R. D., Searle, M.P., 2006. Channel flow, ductile extrusion and exhumation in continental collision zones: an introduction, in Law, R. D., Searle, M. P., Godin, L. (eds) Channel Flow, Ductile Extrusion and Exhumation in Continental Collision Zones. Geological Society, London, Special Publications 268, 1-23.

Greiling, R., 1982. The metamorphic and structural evolution of the Phyllite-Quartzite Nappe of western Crete. Journal of Structural Geology 4, 291-297.

Jolivet, L., Goffe, B., Monie, P., Truffert-Luxey, C., Patriat, M., Bonneau, M., 1996. Miocene detachment in Crete and exhumation P-T-t paths of high-pressure metamorphic rocks. Tectonics 15, 1129-1153.

Katagas, C., Tsolis-Katagas, P., Baltatzis, E., 1991. Chemical mineralogy and illite crystallinity in low grade metasediments, Zarouchla Group, Northern Peloponnesus, Greece. Mineralogy and Petrology 44, 57-71.

Klein, T., Reichhardt, H., Klinger, L., Grigull, S., Wostal, G., Kowalczyk, G., Zulauf, G., 2008. Reverse slip along the contact Phyllite-Quartzite Unit/Tripolitsa Unit in eastern Crete: implications for the geodynamic evolution of the External Hellenides. in Xypolias, P., Zulauf, G. (Eds.), Eastern Mediterranean. Zeitschrift der Deutschen Gesellschaft für Geowissenschaften 159, 375-398.

Kokkalas, S., Doutsos, T., 2001. Strain-dependent field and plate motions in the south-east Aegean region. Journal of Geodynamics 32, 311-332.

Kokkalas, S., Doutsos, T., 2004. Kinematics and strain partitioning in the southeast Hellenides (Greece). Geological Journal 39, 121-140.

Kokkalas, S., Xypolias, P., Koukouvelas, I., and Doutsos, T., 2006. Postcollisional contractional and extensional deformation in the Aegean region, in Dilek, Y., and Pavlides, S., eds., Post-collisional tectonics and magmatism in the Mediterranean region and Asia: Geological Society of America Special Paper 409, p. 97-123.

Kowalczyk, G., Richter, D., Risch, H., Winter, K.P., 1977. Zur zeitlichen Einstufung der tektogenetischen Ereignisse auf dem Peloponnes (Griechenland). Neues Jahrbuch für Geologie und Paläontologie, Monatshefte 1977, 549-564.

Law, R.D., Searle, M.P., Simpson, R.L., 2004. Strain, deformation temperatures and vorticity of flow at the top of the Greater Himalayan Slab, Everest Massif, Tibet. Journal of the Geological Society, London $161,305-320$. 
Lisle, R.J., 1994. Palaeostrain analysis, in Hancock, P.L. (Ed.), Continental Deformation. Pergamon Press, Oxford, 28-42.

Panagos, A.G., Pe-Piper, G.G., Piper, D.J.W., Kotopouli, C.N., 1979. Age and stratigraphic subdivision of the Phyllite series Krokee region Peloponnese Greece. Neues Jahrbuch für Geologie und Paläontologie, Monatshefte 1979, 181-190.

Papanikolaou, D., Vassilakis, E., 2010. Thrust faults and extensional detachment faults in Cretan tectonostratigraphy: Implications for Middle Miocene extension. Tectonophysics, In Press.

Passchier, C.W, 1987. Stable positions of rigid objects in non-coaxial flow-a study in vorticity analysis. Journal of Structural Geology 9, 679-690.

Platt, J.P., 1993. Exhumation of high-pressure rocks: a review of concepts and processes. Terra Nova 5, $119-133$.

Robertson, A.H.F., 2006. Sedimentary evidence from the south Mediterranean region (Sicily, Crete, Peloponnese, Evia) used to test alternative models for the regional tectonic setting of Tethys during Late Palaeozoic-Early Mesozoic time, in Robertson, A.H.F., Mountrakis, D. (Eds.), Tectonic Development of the Eastern Mediterranean region. Geological Society, London, Special Publications 260, 91-154.

Schwarz, S., Stöckhert, B., 1996. Pressure solution in siliciclastic HP-LT metamorphic rocks - constraints on the state of stress in deep levels of accretionary complexes. Tectonophysics 255, 203-209.

Seidel, E., Kreuzer, H., Harre, W., 1982. A late Oligocene/early Miocene high pressure belt in the external Hellenides. Geologisches Jahrbuch E23, 165-206.

Theye, T., Seidel, E., Vidal, O., 1992. Carpholite, sudoite, and chloritoid in low-grade high-pressure metapelites from Crete and the Peloponnese. European Journal of Minerology 4, 487-507.

Thiebault, F., Triboulet, T., 1984. Alpine metamorphism and deformation in Phyllite nappes (external Hellenides, southern Peloponnesus, Greece): Geodynamic implication. The Journal of Geology 92, 185-199.

Thomson, S.N., Stockhert, B., Brix, M.R., 1999. Miocene high-pressure metamorphic rocks of Crete, Greece: rapid exhumation by buoyant escape. In: Ring, U., Brandon, M. T., Lister, G. S., Willet, S. D. (eds) Exhumation Processes: Normal Faulting, Ductile Flow and Erosion. Geological Society, London, Special Publications 154, 87-107.

Thomson, S.N., Stöckhert, B., Rauche, H., Brix, M.R., 1998. Thermochronology of the high-pressure metamorphic rocks of Crete, Greece: implications for the speed of tectonic processes. Geology 26, 259-262.

Tortorici, L., Caputo, R., Monaco, C., 2010. Late Neogene to Quaternary contractional structures in Crete (Greece). Tectonophysics 483, 203-213.

Wallis, S.R., 1995. Vorticity analysis and recognition of ductile extension in the Sanbagawa belt, SW Japan. Journal of Structural Geology 17, 1077-1093.

Xypolias, P., 2009. Some new aspects of kinematic vorticity analysis in naturally deformed quartzites. Journal of Structural Geology, 31, 3-10.

Xypolias, P., Doutsos, T., 2000. Kinematics of rock flow in a crustal-scale shear zone: implication for the orogenic evolution of the southwestern Hellenides. Geological Magazine 137, 81-96.

Xypolias, P., Kokkalas, S., 2006. Heterogeneous ductile deformation along a mid-crustal extruding shear zone: an example from the External Hellenides (Greece), in Law, R.D., Searle, M., Godin, L. (Eds.), Channel flow, ductile extrusion and exhumation in continental collision zones. Geological Society, London, Special Publications 268, 497-516.

Xypolias, P., Koukouvelas, I.K., 2001. Kinematic vorticity and strain rate patterns associated with ductile 
extrusion in the Chelmos Shear Zone (External Hellenides, Greece). Tectonophysics 338, 59-77.

Xypolias, P., Chatzaras, V., Koukouvelas, I.K., 2007. Strain gradients in zones of ductile thrusting: Insights from the External Hellenides. Journal of Structural Geology 29, 1522-1537.

Xypolias, P., Koukouvelas, I.K., Zulauf, G., 2008. Cenozoic tectonic evolution of northeastern Apulia: Insights from a key study area in the Hellenides (Kythira, Greece), in Xypolias, P., Zulauf, G. (Eds.), Eastern Mediterranean. Zeitschrift der Deutschen Gesellschaft für Geowissenschaften 159, 439-455.

Xypolias, P., Spanos, D., Chatzaras, V., Kokkalas, S., Koukouvelas, I., 2010. Vorticity of flow in ductile thrust zones: examples from the Attico-Cycladic Massif (Internal Hellenides, Greece), in Law, R., Butler, R., Holdsworth, B., Krabbendam, M., Strachan, R. (eds) Continental Tectonics and Mountain Building. Geological Society, London, Special Publications 335, In Press.

Zulauf, G., Klein, T., Kowalczyk, G., Krahl, J., Romano, S.S., 2008. The Mirsini Syncline of eastern Crete, Greece: a key area for understanding pre-Alpine and Alpine orogeny in the eastern Mediterranean, in Xypolias, P., Zulauf, G. (Eds.), Eastern Mediterranean. Zeitschrift der Deutschen Gesellschaft für Geowissenschaften 159, 399-414.

Zulauf, G., Kowalczyk, G., Krahl, J., Petschick, R., Schwanz, S., 2002. The tectonometamorphic evolution of high-pressure low-temperature metamorphic rocks of eastern Crete, Greece: constraints from microfabrics, strain, illite crystallinity and paleodifferential stress. Journal of Structural Geology 24, 1805-1828. 
